\title{
Organochlorine Contaminants in the Country Food Diet of the Belcher Island Inuit, Northwest Territories, Canada
}

\author{
MARJORIE CAMERON ${ }^{1,2}$ and I. MICHAEL WEIS ${ }^{1,3}$
}

(Received 19 August 1991; accepted in revised form 17 September 1992)

\begin{abstract}
An initial assessment of the country food diet at the Belcher Islands' community of Sanikiluaq, Northwest Territories, was made by interviewing 16 families during May - July 1989. Estimates of consumption per day were established over a two-week period for 10 of these families. This information was utilized along with previously published harvest data for the community to estimate country food consumption in grams/day and kg/year. Beluga (Delphinapterus leucas), ringed seal (Phoca hispida), arctic charr (Salvelinus alpinus), common eider (Somateria mollissima) and Canada goose (Branta canadensis) were found to be important components in the diet during this period. Results of analysis for organochlorine contaminants reveal that ringed seal fat and beluga muktuk (skin and fat layer) samples have the highest concentration of DDE and total PCBs among the country food species. Average DDE and total PCB values were $1504.6 \mu \mathrm{g} / \mathrm{kg}$ and $1283.4 \mu \mathrm{g} / \mathrm{kg}$ respectively in ringed seal fat and $184.3 \mu \mathrm{g} / \mathrm{kg}$ and $144.7 \mu \mathrm{g} / \mathrm{kg}$ respectively in beluga muktuk. Comparison of contaminants in seal fat indicates concentrations approximately two times higher in samples from the Belcher Islands than from sites in the Canadian Western Arctic, but lower than concentrations reported from various European sites. The daily consumption estimates in grams/day were used along with organic contaminant analysis data to calculate the estimated intake levels of $0.22 \mu \mathrm{g} / \mathrm{kg}$ body weight/day of total DDT and $0.15 \mu \mathrm{g} / \mathrm{kg}$ body weight/day of total PCBs during the study period. Although limited in sample size, studies such as this provide a framework from which to establish future consumption guidelines more applicable to arctic systems and native diets.
\end{abstract}

Key words: organic contaminants, PCBs, DDE and total DDT, Inuit diet, Belcher Islands

RÉSUMÉ. On a procédé à une première évaluation de l'alimentation fournie par la nature dans la communauté de Sanikiluaq des îles Belcher dans les Territoires du Nord-Ouest, en interviewant 16 familles de mai à juillet 1989. Pour 10 de ces familles, on a évalué la consommation quotidienne sur une durée de deux semaines. On a utilisé cette information ainsi que les données de récolte publiées précédemment pour cette communauté afin d'évaluer la consommation d'aliments fournis par la nature en grammes/jour et en $\mathrm{kg} / \mathrm{an}$. On a trouvé que le bélouga (Delphinapterus leucas), le phoque annelé (Phoca hispida), l'omble arctique (Salvelinus alpinus), l'eider à duvet (Somateria mollissima) et la bernache du Canada (Branta canadensis) constituaient un élément important du régime alimentaire au cours de cette période. Les résultats d'analyse portant sur les contaminants organochlorés révèlent que les échantillons de graisse de phoque annelé et de muktuk (couche de peau et de graisse de bélouga) contiennent les concentrations les plus élevées de DDE et de PCB global parmi les espèces servant à l'alimentation fournie par la nature. Les valeurs moyennes de DDE et de PCB global étaient de $1504,6 \mu \mathrm{g} / \mathrm{kg}$ et de $1283,4 \mu \mathrm{g} / \mathrm{kg}$ respectivement dans la graisse de phoque annele et de $184,3 \mu \mathrm{g} / \mathrm{kg}$ et de $144,7 \mu \mathrm{g} / \mathrm{kg}$ respectivement dans le muktuk de bélouga. Une comparaison des contaminants dans la graisse de phoque révèle des concentrations environ deux fois plus élevées dans les échantillons provenant des îles Belcher que d'autres sites de l'Arctique canadien occidental, mais plus faibles que les concentrations signalées dans diverses régions d'Europe. On s'est servi des estimations de consommation quotidienne en grammes/jour, ainsi que des donnés d'analyse de contaminants organiques, pour calculer le niveau d'ingestion estimé correspondant à $0,22 \mu \mathrm{g} / \mathrm{kg}$ de poids corporel/jour pour le DDT global et celui correspondant à $0,15 \mu \mathrm{g} / \mathrm{kg}$ de poids corporel/jour pour le PCB global durant la période d'étude. Bien que l'échantillonnage en soit limité, des études de ce genre offrent un cadre permettant d'établir de futurs schémas de consommation plus adaptés aux systèmes arctiques et aux régimes alimentaires des autochtones.

Mots clés: contaminants organiques, PCB, DDE et DDT global, régime alimentaire des Inuit, îles Belcher

Traduit pour le journal par Nésida Loyer.

\section{INTRODUCTION}

It has been established that measurable concentrations of organochlorine contaminants (OCs) are present throughout the arctic ecosystem (Addison and Smith, 1974; Wageman and Muir, 1984), with oceanic and atmospheric transport cited as the most plausible sources (Oehme and Ottar, 1984; Hargrave et al., 1988; Gregor and Gummer, 1989). Being lipophilic, these OCs are accumulated in sediments and biota and are found within the food web at levels that far exceed the concentrations typical of surrounding waters (Muir et al., 1988; Bidleman $e t$ al., 1989). Contaminant concentrations in the Canadian Arctic vary considerably with respect to location (Andersson et al., 1988; Patton et al., 1989; Muir et al., 1990), and it has been noted that Hudson Bay marine biota have high levels of contamination. It has been suggested that this is a result of $O C$ input through increased precipitation in this region (Norstrom and Muir, 1988).

Due to the dependence of Inuit populations on harvested country foods (Usher, 1977), contamination of the arctic food chain may have important consequences for the native population as well as the arctic ecosystem. Several studies have reported OCs in country food and PCBs in human breast milk (Kinloch et al., 1992; Dewailly et al., 1989). Although extensive harvest data are available for several Inuit communities (James Bay and Northern Quebec Native Harvesting Research Committee, 1982; Quigley and McBride, 1987; Usher and Wenzel, 1987), consumption patterns differ considerably between settlements (Mackay and Orr, 1986). It is important, therefore, to determine the specific dietary trends of the Sanikiluaq community, to assess the OC levels in the consumed biota and to estimate daily OC intake through the diet.

\section{MATERIALS AND METHODS}

This study was conducted at the Inuit settlement of Sanikiluaq $\left(56^{\circ} 72^{\prime} \mathrm{N}, 70^{\circ} 14^{\prime} \mathrm{W}\right)$ on the Belcher Islands in Hudson Bay. Sixteen families from this community agreed to participate in a voluntary diet survey that provided information regarding species hunted, seasonal consumption patterns, the percentage of families consuming these species and tissue preparation. The eldest woman or the male hunter of each family was interviewed

'Department of Biological Sciences and Great Lakes Institute, University of Windsor, Windsor, Ontario, Canada N9B 3P4

${ }^{2}$ Current address: Watershed Ecosystems Program, Trent University, Peterborough, Ontario, Canada K9J 7B8

${ }^{3}$ To whom reprint requests should be addressed

CThe Arctic Institute of North America 
and general information regarding sex, age and occupation was also obtained. All interviews were conducted in Inuktitut and written material was transcribed into syllabics by a translator. A subset of 10 of these families agreed to keep specific food consumption diaries over a 14-day period (from 30 May to 6 July 1989). This provided information regarding approximate food quantities and number of individuals consuming a particular country food within each family. The summary data were confirmed by re-interviewing several of the participating families the following year, revealing that results were representative for this season.

Samples of a variety of meat and fat tissues (10-20 g wet weight), obtained by donation from hunters, were taken from animals being harvested and eaten in the community during the time of this survey. Samples were labelled, wrapped in solvent cleaned foil and then frozen and transported to the Great Lakes Institute at the University of Windsor, stored frozen for six months and analyzed over a three-month period. Each sample (3-5 $\mathrm{g}$ thawed wet weight) was ground with anhydrous sodium sulphate, loaded into a $2.1 \mathrm{~cm}$ by $35 \mathrm{~cm}$ glass column and eluted with a solution of $50 \%$ dichloromethane/petroleum ether. Clean-up was carried out on an activated florisil $(6 \mathrm{~g})$ column eluted in two fractions $(50 \mathrm{ml}$ hexane and $75 \mathrm{ml} 50: 50$ $\mathrm{DCM} /$ hexane). Lipid content of each sample was also determined. Clean-up of fat samples required an additional step involving gel permeation chromatography (GPC; eluting with 55:45 DCM/hexane) prior to florisil clean-up. Analysis for a spectrum of OCs was performed using capillary column gas chromatography (HP $5890 \mathrm{GC}$ equipped with an ${ }^{63} \mathrm{Ni} \mathrm{ECD}$ and a $30 \mathrm{~m} \times 0.25 \mathrm{~mm}$ column with $0.25 \mu \mathrm{m}$ DB-5 film thickness). Contaminants were quantified against known standards and calibrated against sample blanks. All compounds were found to have $95-110 \%$ recovery efficiencies.

Information obtained from the diet diaries, along with previously published annual harvest data and edible weights per animal (Quigley and McBride, 1987; James Bay and Northern Quebec Native Harvest Research Committee, 1982), allowed consumption estimates to be made for the five species that are consumed by over $50 \%$ of the population. Assuming that one "meal" is approximately equivalent to $500 \mathrm{~g}$ (Kuhnlein, 1989), the "meals/week" values were converted to average grams/family/week values. Knowing the percentage of families and individuals in that family who consume a certain country food, the average grams/family/week values were converted to an estimated intake of grams/person/day for these species during the June-July period. Annual consumption estimates were obtained in $\mathrm{kg} /$ year for the same five species by multiplying the edible weight per animal by the total harvest count for the year and dividing by the population size of Sanikiluaq. It should be noted that these harvest estimates are not fully reliable, since seal and beluga meat is often used for dog food. By utilizing results from $O C$ analysis $(\mu \mathrm{g} / \mathrm{kg}$ wet weight) and averaging these intake values over 365 days, estimates of total DDT and PCB intake in $\mu \mathrm{g} /$ person/day were obtained. Due to the fact that data were collected for the family instead of the individual, an average weight per person of $50 \mathrm{~kg}$ is used (Health and Welfare Canada, 1980). Tissue contaminant concentrations (on a wet weight basis) were then used to calculate the maximum daily intake of specific tissue types that comply with the acceptable daily intake (ADI) values for total DDT and PCB consumption (EPA, 1984; EPS, 1987). One standard error was added to the mean concentrations for these calculations to ensure that the highest potential estimate of daily intake was obtained.

\section{RESULTS}

Sanikiluaq, a small community of $\mathbf{4 2 5}$ people, has an even sex distribution ( $52 \%$ o and $48 \% \%)$ and an age distribution strongly skewed to ages below 25 years ( $>50 \%$ ), with few $(<1 \%$ ) over 65 years of age (Fig. 1). The 16 families interviewed represented $25 \%$ of the total population and had an average family size of 7 members. One member of each family was a harvester of some type of country food, representing $16 \%$ of total individuals involved in the survey. Families interviewed ranged from those consuming some store-bought meat to those consuming hunted and caught meats exclusively. This subset was therefore assumed to be an accurate representation of the entire population.

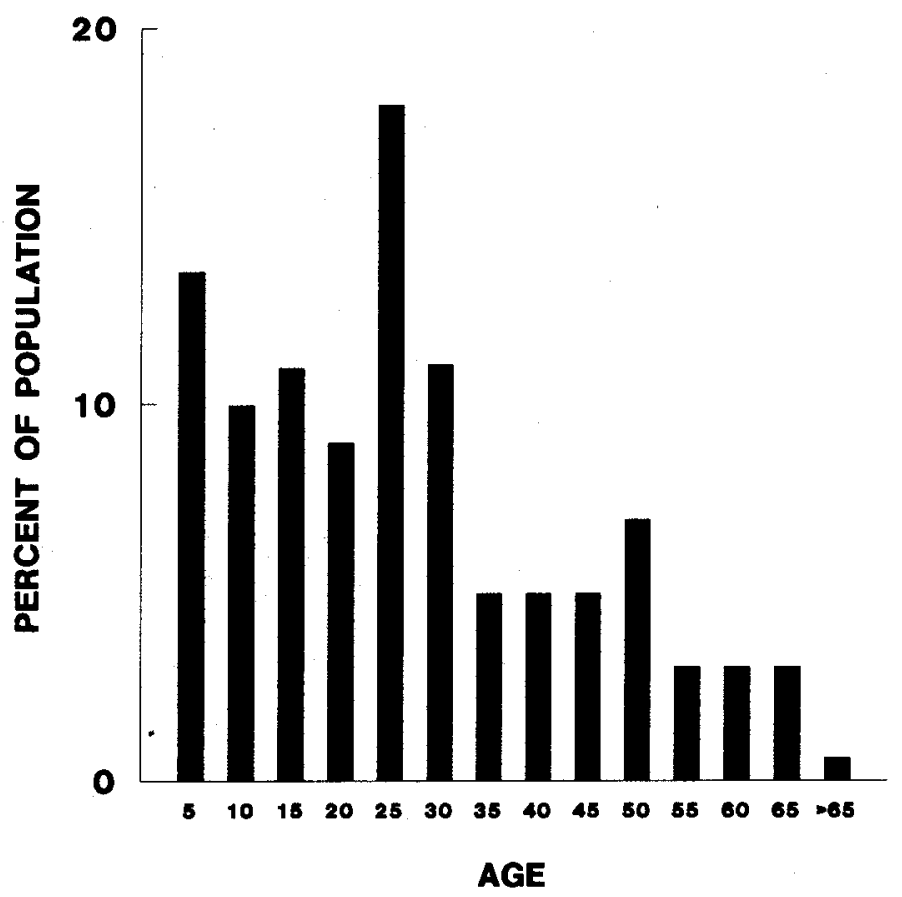

FIG. 1. Age distribution of the Belcher Islands community of Sanikiluaq, 1989.

The information obtained regarding seasonal variation in hunting (Fig. 2) is in agreement with previous findings for this community (Flemming, 1989). Benthic invertebrates are gathered in late winter and during open water when ocean-run charr fishing and beluga whale hunting occur. Ringed seal hunting is confined to months when there is land-fast ice. The resident population of common eider ducks is hunted from June (when eggs are gathered) to January. Geese are hunted during the two migratory periods. Communal hunts for reindeer, under the control of the local Hunters and Trappers Association, occur four times per year. Polar bears are hunted only between December and February. Government quotas (25 tags) strictly limit the number of animals taken (Fig. 2). Although reindeer and polar bear tissues are consumed by the majority of the population, they were not consumed during the period of this study. Ringed seal, beluga, Canada goose and charr are consumed by the entire population; eider ducks are consumed by $94 \%$ of the population. In addition to the seasonal patterns of hunting and fishing, the survey indicated that particular tissues of some species were favoured and others only occasionally consumed (Table 1). The heart and liver of ringed seals are 


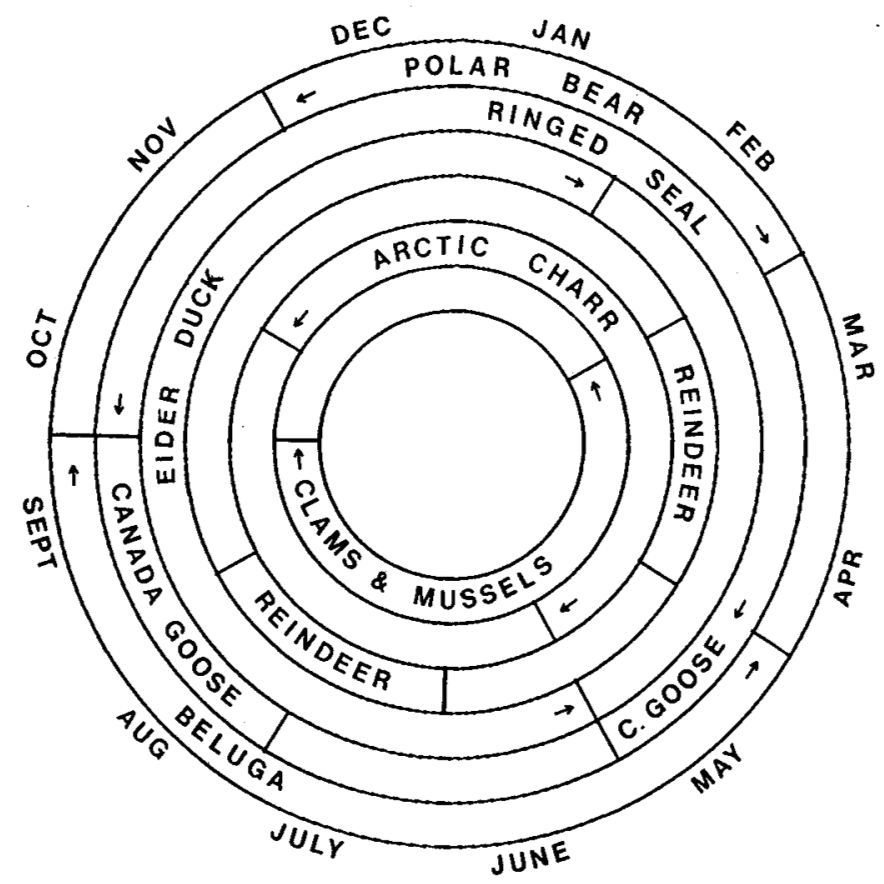

FIG. 2. Seasonal hunting cycle for key species in Inuit diet, 1989. Arcs bounded by dividing lines indicate the duration of seasonal hunts for major country food species. Species are indicated in separate annuli for clarity.

TABLE 1. Results of the general survey regarding the percentage of families harvesting and consuming species, which tissues are consumed and the most common method of preparation

\begin{tabular}{|c|c|c|c|}
\hline \multicolumn{2}{|c|}{ Species and tissue } & $\begin{array}{c}\% \text { families } \\
\text { consuming tissue }\end{array}$ & $\frac{\text { Method of preparation (\%) }}{\text { raw (81) }}$ \\
\hline Ringed seal & $\begin{array}{l}\text { Meat } \\
\text { Liver } \\
\text { Kidney } \\
\text { Fat }\end{array}$ & $\begin{array}{r}100 \\
69 \\
69 \\
44\end{array}$ & $\begin{array}{l}\text { raw }(81) \\
\text { raw }(94) \\
\text { raw }(94)\end{array}$ \\
\hline Beluga & $\begin{array}{l}\text { Meat } \\
\text { Skin and blubber } \\
\text { (muktuk) }\end{array}$ & $\begin{array}{r}100 \\
88\end{array}$ & $\begin{array}{l}\text { dried (75) } \\
\text { raw (94) }\end{array}$ \\
\hline $\begin{array}{l}\text { Canada goo } \\
\text { Eider duck } \\
\text { Charr }\end{array}$ & & $\begin{array}{r}100 \\
94 \\
100\end{array}$ & $\begin{array}{l}\text { boiled }(100) \\
\text { boiled }(100) \\
\text { raw }(94) ; \text { boiled }(94)\end{array}$ \\
\hline
\end{tabular}

frequently consumed raw by hunters and, although not a critical component of the diet, seal fat can be an important source of calories during cold winter hunts. Meat is often boiled; however, much of the country food is still stored frozen and consumed raw (Table 1). In the case of charr, both methods of preparation were used by most of those responding. It is therefore representative of the diet to use raw frozen samples for analyses.

The annual harvested quantities of key species available for this community (Quigley and McBride, 1987) were used along with average edible weight per animal (James Bay and Northern Quebec Native Harvesting Research Committee, 1982) to estimate consumption in $\mathrm{kg} / \mathrm{person} / \mathrm{yr}$. Table 2 presents consumption estimates for the most frequently consumed country food species. Although annual harvest data were available for reindeer, the estimate would not adequately reflect current harvesting due to growth of the reindeer population since the time of the harvest study. As a result, annual consumption was not estimated for this species.
TABLE 2. Annual consumption estimates for key species in the $\operatorname{diet}^{1}$

\begin{tabular}{lrccc}
\hline \hline & $\begin{array}{c}\# \\
\text { harvested } \\
\text { annually }\end{array}$ & $\begin{array}{c}\text { Edible weight } \\
\text { per animal } \\
\text { meat only } \\
(\mathrm{kg})\end{array}$ & $\begin{array}{c}\text { Total } \\
\text { consumption } \\
\text { (kg/year) }\end{array}$ & $\begin{array}{c}\text { Total consumed } \\
\text { per person } \\
\text { (kg/year) }\end{array}$ \\
Species & 3020 & 21.0 & 63420 & 149 \\
Ringed seal & 72 & 372.0 & 26784 & 63 \\
Beluga & 17891 & 2.0 & 35782 & 84 \\
Charr & 7615 & 1.5 & 11422.5 & 27 \\
Eider duck & 4252 & 2.1 & 8929.2 & 21 \\
Canada goose & 4252 &
\end{tabular}

'Data were estimated using annual community harvest values (Quigley and McBride, 1987) and edible weights per animal (James Bay and Northern Quebec Native Harvest Research Committee, 1982).

The diet diaries completed by 10 families provide a sketch of country food quantities consumed during a two-week period between late May and early July 1989 . The percentage values of participating families and individuals in that family consuming a certain country food were used along with the average number of "meals" per week of that country food to estimate the intake in grams/person/day (Table 3). Not surprisingly, these results do not match the pattern of consumption averaged over the full year. Species abundant year round are harvested only when seasonal favourites are not available. All families consumed some type of country meat on $80 \%$ of the days within the two-week diary period. During this time, $27 \%$ of all meals included ocean-run charr (Salvelinus alpinus), 17\% included eider (Somateria mollissima), 16\% Canada goose (Branta canadensis), $12 \%$ ringed seal (Phoca hispida), $11 \%$ beluga (Delphinapterus leucas) muktuk (skin and fat) and $10 \%$ beluga meat. No other species was consumed in over $2 \%$ of the meals. Tissues from charr, eider duck, Canada goose, beluga (muktuk and meat) and ringed seal constituted approximately $85 \%$ of the country food consumed during the study period and were the focus of our $O C$ analysis.

TABLE 3. Consumption estimates for key species in diet during the months of May-July $1989^{1}$

\begin{tabular}{lccccc}
\hline \hline & $\begin{array}{c}\text { Average } \\
\text { \# meals } \\
\text { /week } \\
\text { /family }\end{array}$ & $\begin{array}{c}\text { Average } \\
\text { \# grams } \\
\text { /week } \\
\text { /family }\end{array}$ & $\begin{array}{c}\% \\
\text { families } \\
\text { eating } \\
\text { tissue }\end{array}$ & $\begin{array}{c}\% \\
\text { people } \\
\text { eating } \\
\text { /family }\end{array}$ & $\begin{array}{c}\text { Grams } \\
\text { /day } \\
\text { /person }^{3}\end{array}$ \\
Species & 1.1 & 550 & 70 & 51 & 28 \\
Ringed seal meat & 0.65 & 325 & 60 & 70 & 19 \\
Beluga meat & 1.13 & 565 & 60 & 70 & 33 \\
Beluga muktuk & 1.8 & 900 & 70 & 76 & 68 \\
Charr & 0.63 & 315 & 80 & 76 & 27 \\
Eider & 1.5 & 750 & 50 & 60 & 32 \\
Canada goose & C.6
\end{tabular}

'Data were estimated using diet diaries from 10 families (70 individuals).

${ }^{2}$ Calculated by multiplying the average number of meals/week/family by an estimated 500 grams per day (Kuhnlein, 1989).

${ }^{3} \mathrm{Calculated}$ by multiplying average grams/week/family by the percentage of families eating and the percentage of people eating/family. This was converted to consumption on a daily basis for an average individual.

The results of tissue analysis confirmed the presence of OCs within the aquatic food chain at Sanikiluaq (Table 4). Detection was possible in clams for only three different OCs (at the $0.5 \mu \mathrm{g} / \mathrm{kg}$ range for trans-nonachlor, DDE and several PCB congeners). Canada geese, which are primary consumers and migratory, were found to have similarly low OC levels in the single analysis from this sample set and in an analysis of a pooled sample representing ten birds made available by the Canadian Wildlife Service (Braune, pers. comm. 1991). OC input from 
TABLE 4. Average concentrations of organic contaminants in tissues of country foods collected at Sanikiluaq, N.W.T. ( $\mu \mathrm{g} / \mathrm{kg}$ wet weight) ${ }^{1}$

\begin{tabular}{|c|c|c|c|c|c|c|c|c|c|}
\hline & \multicolumn{4}{|c|}{ Ringed Seal } & \multicolumn{2}{|c|}{ Beluga } & \multirow[b]{2}{*}{$\operatorname{Eider}^{3}(n=12)$} & \multirow[b]{2}{*}{ Charr $(n=6)$} & \multirow[b]{2}{*}{ Clams $(n=6$} \\
\hline & Meat $(n=4)$ & Kidney $(n=2)$ & Liver $(n=3)$ & Fat $(n=3)$ & Meat $(n=2)$ & Muktuk $(n=2)$ & & & \\
\hline \% LIPID & 1.83 & 2.43 & 3.25 & 87.20 & 1.42 & 62.72 & 2.79 & 1.95 & 1.78 \\
\hline$\alpha-\mathrm{HCH}$ & $\begin{array}{c}2.8 \\
(1.4)\end{array}$ & 4.1 & $\begin{array}{c}7.2 \\
(1.6)\end{array}$ & $\begin{array}{c}406.1 \\
(158.2)\end{array}$ & 1.3 & 8.9 & $\begin{array}{c}0.2 \\
(0.1)\end{array}$ & $\begin{array}{c}0.8 \\
(0.2)\end{array}$ & n.d. \\
\hline$\Sigma$-HCH & $\begin{array}{c}3.3 \\
(1.7)\end{array}$ & 4.4 & $\begin{array}{l}7.6 \\
(1.9)\end{array}$ & $\begin{array}{c}434.5 \\
(174.7)\end{array}$ & 1.5 & 12.5 & $\begin{array}{c}0.9 \\
(0.4)\end{array}$ & $\begin{array}{c}0.8 \\
(0.2)\end{array}$ & n.d. \\
\hline oxy-Chlordane & $\begin{array}{l}12.4 \\
(8.3)\end{array}$ & 3.7 & $\begin{array}{c}1.6 \\
(4.3)\end{array}$ & $\begin{array}{c}206.2 \\
(91.9)\end{array}$ & 0.7 & 22.4 & $\begin{array}{c}2.0 \\
(0.4)\end{array}$ & $\begin{array}{c}0.4 \\
(0.03)\end{array}$ & n.d. \\
\hline$\Sigma$-Chlordane & $\begin{array}{l}12.8 \\
(8.5)\end{array}$ & 3.9 & $\begin{array}{c}1.9 \\
(4.4)\end{array}$ & $\begin{array}{c}214.4 \\
(96.7)\end{array}$ & 1.2 & 26.6 & $\begin{array}{c}2.1 \\
(0.4)\end{array}$ & $\begin{array}{c}0.8 \\
(0.1)\end{array}$ & n.d. \\
\hline trans-Nonachlor & $\begin{array}{c}6.2 \\
(4.1)\end{array}$ & 2.6 & $\begin{array}{c}3.8 \\
(1.2)\end{array}$ & $\begin{array}{l}162.1 \\
(58.4)\end{array}$ & 3.3 & 106.3 & 1.2 & $\begin{array}{c}1.4 \\
(0.3)\end{array}$ & $\begin{array}{c}0.5 \\
(0.1)\end{array}$ \\
\hline$\Sigma$-Nonachlor & $\begin{array}{c}7.0 \\
(4.3)\end{array}$ & 2.8 & $\begin{array}{c}3.9 \\
(1.3)\end{array}$ & $\begin{array}{l}178.4 \\
(65.6)\end{array}$ & 3.8 & 136.7 & 1.5 & $\begin{array}{c}1.8 \\
(0.4)\end{array}$ & $\begin{array}{c}0.5 \\
(0.1)\end{array}$ \\
\hline Dieldrin & $\begin{array}{c}4.9 \\
(2.6)\end{array}$ & 1.6 & $\begin{array}{l}15.4 \\
(5.4)\end{array}$ & $\begin{array}{c}187.2 \\
(112.5)\end{array}$ & 4.6 & 35.6 & $\begin{array}{c}2.0 \\
(0.6)\end{array}$ & $\begin{array}{c}1.4 \\
(0.3)\end{array}$ & n.d. \\
\hline pp'-DDT & $\begin{array}{c}6.1 \\
(1.7)\end{array}$ & 1.2 & $\begin{array}{c}1.2 \\
(1.2)\end{array}$ & $\begin{array}{l}129.9 \\
(16.2)\end{array}$ & 1.4 & 68.6 & n.d. & n.d. & n.d. \\
\hline$p p^{\prime}-\mathrm{DDD}$ & $\begin{array}{c}1.3 \\
(0.7)\end{array}$ & 0.4 & $\begin{array}{c}2.3 \\
(0.5)\end{array}$ & $\begin{array}{l}17.0 \\
(8.1)\end{array}$ & 1.2 & 19.3 & $\begin{array}{c}0.8 \\
(0.7)\end{array}$ & n.d. & n.d. \\
\hline$p p^{\prime}-D D E$ & $\begin{array}{c}33.2 \\
(27.8)\end{array}$ & 12.8 & $\begin{array}{c}35.8 \\
(14.9)\end{array}$ & $\begin{array}{l}1504.6 \\
(739.7)\end{array}$ & 0.8 & 184.3 & $\begin{array}{c}4.8 \\
(0.7)\end{array}$ & $\begin{array}{c}3.3 \\
(0.4)\end{array}$ & $\begin{array}{c}0.6 \\
(0.2)\end{array}$ \\
\hline PCB $\# 99$ & $\begin{array}{l}14.7 \\
(4.7)\end{array}$ & 4.9 & $\begin{array}{l}16.3 \\
(5.9)\end{array}$ & $\begin{array}{c}290.1 \\
(111.3)\end{array}$ & 2.7 & 63.8 & $\begin{array}{c}1.0 \\
(0.1)\end{array}$ & $\begin{array}{c}1.7 \\
(0.3)\end{array}$ & n.d. \\
\hline PCB \#138 & $\begin{array}{r}8.7 \\
(2.2)\end{array}$ & 2.5 & 7.9 & $\begin{array}{c}217.3 \\
(69.3)\end{array}$ & 0.6 & 2.3 & $\begin{array}{c}0.9 \\
(0.1)\end{array}$ & $\begin{array}{c}1.6 \\
(0.2)\end{array}$ & $\begin{array}{c}0.1 \\
(0.04)\end{array}$ \\
\hline PCB \#153 & $\begin{array}{c}4.6 \\
(1.7)\end{array}$ & 3.3 & $\begin{array}{l}11.0 \\
(1.9)\end{array}$ & $\begin{array}{l}311.8 \\
(80.3)\end{array}$ & 1.2 & 24.9 & $\begin{array}{c}2.1 \\
(0.4)\end{array}$ & $\begin{array}{c}1.9 \\
(0.2)\end{array}$ & $\begin{array}{c}0.2 \\
(0.02)\end{array}$ \\
\hline$\Sigma-\mathrm{PBCs}^{2}$ & $\begin{array}{c}42.5 \\
(13.3)\end{array}$ & 15.4 & $\begin{array}{c}73.9 \\
(15.9) \\
\end{array}$ & $\begin{array}{l}1283.4 \\
(322.8) \\
\end{array}$ & 6.8 & 144.7 & $\begin{array}{c}5.6 \\
(1.1) \\
\end{array}$ & $\begin{array}{c}8.1 \\
(1.3) \\
\end{array}$ & $\begin{array}{l}1.1 \\
(0) \\
\end{array}$ \\
\hline
\end{tabular}

1Standard errors are given in parentheses. (n.d. represents concentrations below detection limits.)

${ }^{2} \Sigma$-PCBs includes congeners $99,101,118,138,153,170 / 190,180,182 / 187,183,201$ and 203.

${ }^{3}$ Data for eiders include the results of 10 birds analyzed for the Canadian Wildlife Service and two samples provided by donation during this study.

goose meat was therefore considered negligible with respect to overall native contaminant intake through the diet. Although widely consumed during the study period, this was not included as one of the species used to estimate contaminant intake.

Table 4 is a summary of average concentrations $(\mu \mathrm{g} / \mathrm{kg}$ wet weight) for key species and tissue types. Although this study had limited sample sizes, results parallel previous studies of contaminant distribution in the arctic trophic web (Muir et al., 1988). Highest contaminant concentrations were found in the fatty blubber tissues of ringed seal and beluga, with total PCB and DDT levels being highest among analyzed contaminants.

Although found in lower concentrations than DDE and PCBs, several other OCs are notable. The insecticide Lindane contains gamma-HCH, which is transformed into the alpha-isomer by ultraviolet light (Oehme and Ottar, 1984). The alpha form exceeds all other $\mathrm{HCH}$ isomer concentrations in all samples, with highest levels being found in seal fat $(406.1 \mu \mathrm{g} / \mathrm{kg})$. The cyclodienes are a group of insecticides that includes aldrin, dieldrin and chlordane (Broomhall and Kovar, 1986). Dieldrin, a persistent metabolite of aldrin, is found here at highest levels in seal fat $(187.2 \mu \mathrm{g} / \mathrm{kg})$. All other samples contained levels lower than $50 \mu \mathrm{g} / \mathrm{kg}$. The trans isomer of chlordane was undetectable in almost all samples; however, the more stable cis isomer was present at low concentrations. Oxychlordane is a metabolite of cis and trans-chlordane and was present in all samples in much higher quantities than the original compounds (Table 4).

Average OC concentrations were used in conjunction with consumption estimates for the four key species to calculate total dietary contaminant intake in $\mu \mathrm{g} /$ person/day. Daily intake levels from the harvest data (Table 2) were calculated using total tissue concentrations, excluding fat concentrations for seals. Ringed seal fat was not consumed during the study period and data were not available for seasonal fat consumption. It was estimated that average intake for total PCBs and DDT over the entire year would be 128.7 and $170.9 \mu \mathrm{g} /$ person/day respectively (see methods). This translates into $2.6 \mu \mathrm{g} \mathrm{PCBs} / \mathrm{kg}$ body weight/day and $3.4 \mu \mathrm{g} \mathrm{DDT} / \mathrm{kg}$ body weight/day. It was estimated from the diet diary data (Table 3 ) that an average individual consumed 7.3 and $11.5 \mu \mathrm{g} /$ day of total PCBs and DDT respectively (Table 5). This can be converted to an intake of $0.15 \mu \mathrm{g} / \mathrm{kg}$ body weight/day for total PCBs and $0.2 \mu \mathrm{g} / \mathrm{kg}$ body weight/day for total DDT. Estimates made using the annual harvest data are considerably higher and less accurate due to the fact that 
TABLE 5. Estimated intake of $\Sigma$-DDT and $\Sigma$-PCBs $(\mu \mathrm{g} / \mathrm{kg}$ tissue from Table 4) for key country food species using consumption data (kg/day) from Table $3^{1}$

\begin{tabular}{|c|c|c|c|c|c|c|c|}
\hline & $\begin{array}{l}\text { Ringed } \\
\text { seal fat }\end{array}$ & $\begin{array}{c}\text { Ringed } \\
\text { seal } \\
\text { meat }\end{array}$ & $\begin{array}{c}\text { Beluga } \\
\text { meat }\end{array}$ & $\begin{array}{l}\text { Beluga } \\
\text { muktuk }\end{array}$ & $\begin{array}{l}\text { Eider } \\
\text { duck }\end{array}$ & Charr & Total \\
\hline $\begin{array}{l}\text { Consumption } \\
\text { (kg meat/person/day) }\end{array}$ & - & 0.028 & 0.019 & 0.033 & 0.027 & 0.068 & \\
\hline $\begin{array}{l}\Sigma \text {-DDT }(\mu \mathrm{g} / \mathrm{kg}) \\
\text { Contaminant intake } \\
(\Sigma-\mathrm{DDT} / \text { person/day })\end{array}$ & 2415.5 & 70.8 & 3.4 & 272.2 & 7.0 & 3.7 & \\
\hline $\begin{array}{l}\text { ( } \mu \mathrm{g}) \\
\text { Acceptable daily } \\
\text { consumption } \\
\text { (kg/day) }\end{array}$ & 0.01 & 1.98 & 0.06 & 8.98 & 0.19 & 0.25 & 11.46 \\
\hline $\begin{array}{l}\Sigma-P C B s(\mu g / k g) \\
\text { Contaminant intake } \\
(\Sigma-P C B s / \text { person/day) }\end{array}$ & 1606.3 & 55.7 & 6.8 & 144.7 & 6.7 & 9.4 & \\
\hline $\begin{array}{l}(\mu \mathrm{g}) \\
\text { Acceptable daily } \\
\text { consumption }(\mathrm{kg} / \text { day })\end{array}$ & 0.03 & 0.89 & 7.30 & 0.34 & 7.14 & 5.56 & 7.27 \\
\hline
\end{tabular}

In addition, allowable intakes of key species are given for these key species from tissue concentrations and allowable daily intakes (ADIs) for DDT $(0.5 \mu \mathrm{g} / \mathrm{kg}$ body weight/day) and PCBs $(1.0 \mu \mathrm{g} / \mathrm{kg}$ body weight $/ \mathrm{day})$ based on an average individual weight of $50 \mathrm{~kg}$ (Health and Welfare, 1980).

unknown quantities of ringed seal and beluga meat are used for dog food. Table 5 provides an estimate of the maximum consumption of tissues of these key species (in $\mathrm{kg} / \mathrm{day}$ ) that remains below the acceptable EPS daily intake (ADI) levels for total DDT and PCBs (EPS, 1987).

\section{DISCUSSION}

The town of Sanikiluaq is the only permanent settlement on the Belcher Islands. This community maintains a close-knit family social structure with the majority of dietary and hunting habits originating from this structural framework. Other than soapstone carving and the limited fur trade, there is little or no industry in this region (Quigley and McBride, 1987), and an adequate diet for most families would be impossible without country food.

The general survey confirmed community reliance on country foods year round and provided information regarding seasonal variation in species hunted and tissues consumed (Fig. 2; Table 1). The community harvest data used to calculate annual consumption (Table 2) is not fully indicative of human intake, since some harvested meat (primarily ringed seal and some beluga meat) is used for dog food. There are also simplifications made in establishing daily consumption (Table 3 ) using the diary information in that the total family diet is converted into average individual consumption values. The age structure and differences in consumption as a function of age have not been incorporated into these calculations. By taking these two estimates into consideration, however, a more complete picture of the contaminant intake due to several key species is possible.

Samples from those key species that were being hunted and consumed at the time of the study are the focus of our discussion. The data in Table 4 indicate that DDE was found in species of the lower trophic levels, such as charr $(3.3 \mu \mathrm{g} / \mathrm{kg})$, and in elevated concentrations in seal fat $(1504.6 \mu \mathrm{g} / \mathrm{kg})$ and beluga muktuk (184.3 $\mu \mathrm{g} / \mathrm{kg}$ ). Several PCB congeners (IUPAC \#99, \#138 and \#153; Ballschmitter and Zell, 1980) were detected in virtually all tissues analyzed in this study (Table 4). These results parallel the relative concentrations of these congeners in other arctic regions (Muir et al., 1986, 1988). Total PCBs in charr $(8.1 \mu \mathrm{g} / \mathrm{kg})$ and eider duck $(5.7 \mu \mathrm{g} / \mathrm{kg})$ were similarly lower than concentrations in seal and beluga. Highest levels (total PCBs) were found in seal fat $(1283.4 \mu \mathrm{g} / \mathrm{kg}$ ) and beluga muktuk $(144.7 \mu \mathrm{g} / \mathrm{kg})$. The OC concentrations in beluga muktuk samples from this region were found to be lower than those in ringed seal fat. The fact that beluga $O C$ levels here are much lower than concentrations reported in west Hudson Bay beluga (Norstrom and Simon, 1990) could be due to sampling of younger animals, since age was not assessed in Belcher Island samples. This difference may also be explained by the lower lipid content of beluga muktuk (skin and fat) compared to fat only, which is normally analyzed.

An interesting comparison of contaminant concentrations can be made between Belcher Island samples and data from other sites in arctic Canada and northern Europe. There has long been an interest in contamination of marine biota and several studies of OC concentrations in the ringed seal species (Phoca hispida) are available (Drescher et al., 1977; Addison and Brodie, 1987; Ronald et al., 1984; Reijnders, 1986; Norstrom and Muir, 1988; Luckas et al., 1990). Drawing on recent data, Table 6 compares concentrations of major contaminant groups in ringed seal fat among three Canadian sites and three sites in northern Europe. Concentrations of PCBs and chlordanes are total concentrations of related contaminants, and data from the Belcher Islands have been lipid normalized for comparison purposes. It is apparent that seal blubber from the Belcher region contains higher levels of PCBs and DDE than samples from sites at higher latitudes in the Canadian Arctic but generally lower concentrations than samples from northern Europe. Due to the fact that the Inuit from Sanikiluaq and the native populations of northern Quebec rely heavily on country foods, elevated contaminant levels in species such as ringed seal require further detailed investigation.

TABLE 6. A comparison of organic contaminants in seal fat from the Canadian and European Arctic (concentrations lipid normalized, expressed as $\mu \mathrm{g} / \mathrm{kg}$ lipid) ${ }^{1}$

\begin{tabular}{|c|c|c|c|c|c|c|}
\hline Contaminant & $\begin{array}{l}\text { Belcher } \\
\text { Island }\end{array}$ & $\begin{array}{l}\text { Admiralty } \\
\text { Inlet }\end{array}$ & $\begin{array}{c}\text { Barrow } \\
\text { Strait }\end{array}$ & $\begin{array}{l}\text { Spitzbergen, } \\
\text { Norway }\end{array}$ & $\begin{array}{l}\text { Baltic Sea, } \\
\text { Sweden }\end{array}$ & Iceland \\
\hline $\begin{array}{l}\text { Total } \\
\text { PCB }\end{array}$ & 1683.2 & $\begin{array}{l}7940 \\
308 \%\end{array}$ & $\begin{array}{l}5680 \\
375 \text { @ }\end{array}$ & 2535 & 84682 & 5219 \\
\hline $\begin{array}{l}\text { PCB } \\
\# 153\end{array}$ & 357.5 & 220 & 189 & 302 & 10217 & 639 \\
\hline DDE & 1725.5 & $\begin{array}{l}9180 \\
247 \%\end{array}$ & $\begin{array}{l}323 \sigma \\
331 \text { \% }\end{array}$ & 869 & 12758 & 1185 \\
\hline Chlordanes & 450.5 & 463 & 457 & - & - & - \\
\hline
\end{tabular}

'Data for Admiralty Inlet and Barrow Strait sites are from Muir et al. (1988) and for European sites from Luckas et al. (1990).

Contaminant intake through country food was estimated for total DDT and PCBs from those species that composed the bulk of the Inuit diet during this study. Canada geese were excluded from this due to negligible OC levels. As noted in the results, the daily $\mathrm{OC}$ intake estimates from the annual harvest data were higher than those from the diet diaries. In part, this is due to seasonal variation in species harvested throughout the year (Fig. 2). Beluga, arctic charr and ringed seal are dominant species in estimating biomass consumed annually (Table 2). However, during the period of late May to early June, seal 
hunting is essentially over and the beluga hunt will not begin until there is open water. Charr, Canada goose and eider duck are therefore important to the diet during this period (Table 3). These species have lower contaminant concentrations; hence the lower $O C$ intake values obtained for this period.

The estimates of contaminant intake from the diet diaries appear to be below the acceptable daily intake (ADI) for PCBs (1 $\mu \mathrm{g} / \mathrm{kg}$ body weight/day: EPS, 1987) and DDT $(0.5 \mu \mathrm{g} / \mathrm{kg}$ body weight/day: EPA, 1984). Although estimates from the harvest data are higher ( 3.4 and $2.6 \mu \mathrm{g} / \mathrm{kg}$ body weight/day for total DDT and PCBs respectively), the difficulty in determining what fraction of harvested seal biomass is consumed by the Inuit population suggests that our calculation overestimates contaminant intake; these estimates do not provide any immediate reason to forego consumption of country food. Consideration must be given to the fact that these values are estimates calculated to represent the average individual from this community. As a result, it also becomes difficult to compare results of this study to other research on Inuit diets. An extensive dietary survey on Broughton Island indicated that approximately $20 \%$ of the individuals exceeded the ADI for PCBs (Kinloch et al., 1992). Tolerable consumption levels for Broughton Island were calculated using contaminant data from local biota (Kinloch et al., 1992). Intake levels of $100 \mathrm{~g} /$ day of ringed seal fat, $500 \mathrm{~g} /$ day of ringed' seal meat and $2000 \mathrm{~g} /$ day of charr meat were found to be acceptable for a $50 \mathrm{~kg}$ individual given the ADI for total PCBs (Kinloch et al., 1992; EPS, 1987). It must be noted in comparing these two studies that average concentrations from the Belcher region are estimated from a small sample size and that consumption and contaminant levels of key species differ between the two communities (Table 5; Kinloch et al., 1992). Further study and additional analyses are required in the Belcher Islands region to be able to compare these two sites with more confidence. Due to the fact that the dominant proportion of the population of most northern communities is in the juvenile and adolescent categories, OCs in the diet may pose a serious problem. Acceptable levels of contaminants in the diet are established on the basis of intake per kg body weight and children may more easily exceed these standards due to their low weight. Infants face input of high levels of OCs through mother's milk as a result of contaminant mobilization from the maternal body burden, as well as the mother's current dietary intake (Broomhall and Kovar, 1986; Dewailly et al., 1989). Although it is important to monitor these OC levels, it is also of critical importance to emphasize the cultural and nutritional value of country food (Kinloch et al., 1992) and the benefits of breast-feeding babies. Reliance of northern communities on country food necessitates continued in-depth study to fully evaluate dietary intake of OCs and the effects of these contaminants on health and development. Further research is also required to establish consumption guidelines more applicable to northern diets, taking into consideration the seasonal hunting patterns and differences in $\mathrm{OC}$ concentrations for this and other communities.

\section{ACKNOWLEDGEMENTS}

Thanks to the hamlet of Sanikiluaq: the Hamlet Office, the Nursing station, the Hunters and Trappers Association and the Hamlet Council, as well as all those families participating in the survey and donating samples. We would also like to thank Johnny Meeko, Jr., Elizabeth Kudluarok, Dinah Kavik and Lizzie Kavik for their help in interpreting and translating both written materials and verbal interviews between Inuktitut and English. We wish also to thank Margaret Lawrence, Mina Appaqaq, Joe Kowtook, Sr., and Marie Weesk for support and assistance during the study. This study would not have been possible without the assistance of the Great Lakes Institute, University of Windsor, and its staff, particularly Dr. Rudica Lazar. The cooperation of Birgit Braune and the Canadian Wildlife Service in sharing results of a study of migratory wildfowl and Dr. H. Kuhnlein for sending preliminary data regarding the Broughton Island Study are also acknowledged with thanks. The study was supported by an NSTP grant to M.C. and an NSERC operating grant to I.M.W.

\section{REFERENCES}

ADDISON, R.F., and BRODIE, P.F. 1987. Transfer of organochlorine residues from blubber through the circulatory system in milk in the lactating grey seal (Halichoerus grypus). Canadian Journal of Fisheries and Aquatic Sciences 44:782-786.

ADDISON, R.F., and SMITH, T.G. 1974. Organochlorine residue levels in arctic ringed seals: Variation with age and sex. Oikos 25:335-337.

ANDERSSON, O., LINDER, C.E., OLSSON, M., REUTERGARDH, L., UVEMO, U.B., and WIDEQVIST, U. 1988. Spatial differences and temporal trends of organochlorine compounds in biota from the northwestern hemisphere. Archives of Environmental Contamination and Toxicology 17:755-765.

BALLSCHMITTER, K., and ZELL, M. 1980. Analysis of polychlorinated biphenyls (PCBs) by capillary gas chromatography, composition of technical Arochlor- and Clophen-PCB mixtures. Fresenius - Zeitschrift fur Analytische Chemie 302:20.

BIDLEMAN, T.F., PATTON, G.W., WALLA, M.D., HARGRAVE, B.T., VASS, W.P., ERICKSON, P., FOWLER, B., SCOTT, V., and GREGOR, D.J. 1989. Toxaphene and other organochlorines in arctic ocean fauna: Evidence for atmospheric delivery. Arctic 42(4):307-313.

BROOMHALL, J., and KOVAR, Z. 1986. Environmental pollution in breast milk. Review Environmental Health 5:311-337.

DEWAILLY, E., NANTEL, A., WEBER, J-P., and MEYER, F., 1989. High levels of PCBs in breast milk of Inuit women from arctic Quebec. Bulletin of Environmental Contamination and Toxicology 43:641-646.

DRESCHER, H.E., HARMS, U., and HUSCHENBETH, E. 1977. Organochlorines and heavy metals in the harbour seal Phoca vitulina from the German North Sea coast. Marine Biology 41:99-106.

ENVIRONMENTAL PROTECTION AGENCY (EPA). 1984. Report from the Environmental Effects Branch, Health and Environmental Review Division, Office of Toxic Substances. Washington, D.C.

EPS. 1987. Summary of environmental criteria for chlorinated biphenyls (PCBs). Report EPS 4/HA/1. Revised October 1987. Ottawa: Environment Canada.

FLEMING, B. 1989. Working at leisure: Inuit subsistence in an era of animal protection. M.A. thesis, University of Alberta, Edmonton, Alberta.

GREGOR, D.J., and GUMMER, W.D. 1989. Evidence of atmospheric transport and deposition of organochlorine pesticides and polychlorinated biphenyls in Canadian arctic snow. Environmental Science and Technology 23:561-565.

HARGRAVE, B.T., VASS, W.P., ERICKSON, P.E., and FOWLER, B.R. 1988. Atmospheric transport of organochlorines to the arctic ocean. Tellus 40b:480-493.

HEALTH AND WELFARE CANADA. 1980. Nutrition Canada. Anthropometry Report. Ottawa.

JAMES BAY AND NORTHERN QUEBEC NATIVE HARVESTING RESEARCH COMMITTEE. 1982. Research to establish present levels of Native harvesting by the Inuit of Northern Quebec, Phase II (years 1979 and 1980). Montreal: Makivic Corp.

KINLOCH, D., KUHNLEIN, H.V., and MUIR, D. 1992. Inuit foods and diet. A preliminary assessment of benefits and risks. Science of the Total Environment 122:245-276.

KUHNLEIN, H.V. 1989. Nutritional and toxicological components of the Inuit diets in Broughton Island, Northwest Territories. Yellowknife: Department of Health. SC-244137-NWT.

LUCKAS, B., VETTER, W., FISHER, P., HEIDEMANN, G., and PLOTZ, J. 1990. Characteristic chlorinated hydrocarbon patterns in the blubber of seals from different marine regions. Chemosphere 21:13-19.

MACKAY, M.G.A., and ORR, R.D. 1986. An evaluation of household country food use in Makovik, Labrador, July 1980-June 1981. Arctic 40(1):60-65. 
MUIR, D.C.G., FORD, C.A., GRIFT, N.P., METNER, D.A., and LOCKHART, W.L. 1990. Geographic variation of chlorinated hydrocarbons in burbot (Lota lota) from remote lakes and rivers in Canada. Archives of Environmental Contamination and Toxicology 19:530-542.

MUIR, D.C.G., NORSTROM, R.J., and SIMON, M. 1988. Organochlorine contaminants in arctic marine food chains: Accumulation of specific polychlorinated biphenyls and chlordane-related compounds. Environmental Science and Technology 22:1071-1079.

MUIR, D.C.G., WAGEMANN, R., HARGRAVE, B.T., THOMAS, D.J., PEAKALL, D.B., and NORSTROM, R.J. 1992. Arctic marine ecosystem contamination. Science of the Total Environment 122:75-134.

MUIR, D.C.G., WAGEMANN, R., LOCKHART, W.L., CRIFT, N.P., BILLOCK, B., and METNER, D. 1986. Heavy metal and organic contaminants in arctic marine fishes. Ottawa: Department of Indian and Northern Affairs Canada. Environmental Studies \#42.

NORSTROM, R.J., and MUIR, D.C.G. 1988. Long range transport of organochlorines in the arctic and sub-arctic: evidence from analysis of marine mammals and fish. In: Schmidke, N.W., ed. Toxic contamination in large lakes. Vol. II. Chronic effects of toxic contamination in large lakes. Chelsea, Michigan: Lewis. 83-112.

NORSTROM, R.J., and SIMON, M. 1990. Polychlorinated dibenzo-p-dioxins and dibenzofurans in marine mammals in the Canadian North. Environmental Pollution 66:1-19.
OEHME, M., and OTTAR, B. 1984. The long range transport of polychlorinated hydrocarbons to the Arctic. Geophysical Research Letters 11:1133-1136.

PATTON, G.W., HINCKLEY, D.A., WALLA, M.D., and BIDDLEMAN, T.F. 1989. Airborne organochlorines in the Canadian High Arctic. Tellus 41b:243-255.

QUIGLEY, N.C., and McBRIDE, N.J. 1987. The structure of an arctic microeconomy: The traditional sector in community economic development. Arctic 40(3):204-210.

REIJNDERS, P.J.H. 1986. Organochlorine and heavy metal residues in harbour seals from the Wadden Sea and their possible effects on reproduction. Netherlands Journal Sea Research 14:30-65.

RONALD, K., FRANK, R.J., DOUGAN, J.L., FRANK, R., and BRAUN, H.E. 1984. Pollutants in harp seals (Phoca groenlandica) I. organichlorines. Science of the Total Environment 38:133-152.

USHER, P.J. 1977. Evaluating country food in the northern native economy. Arctic 29:105-120.

USHER, P.J., and WENZEL, G. 1987. Native harvest surveys and statistics: A critique of their construction and use. Arctic 40(2):145-160.

WAGEMANN, R., and MUIR, D.G. 1984. Concentrations of heavy metals and organochlorines in marine mammals of northern waters; overview and evaluation. Canadian Technical Reports of Fisheries and Aquatic Sciences no. 1279. 